\title{
Kimberlites, accelerated erosion and evolution of the lithospheric mantle beneath the Kaapvaal craton during the mid-Cretaceous
}

\author{
Brown, R.W. ${ }^{1}$, Gallagher, K. ${ }^{2}$, Griffin, W.L. ${ }^{3}$, Ryan, C.G. ${ }^{3}$, de Wit, M.C.J., ${ }^{4}$ \\ Belton, D.X. ${ }^{1}$ and Harman, R. ${ }^{2}$
}

1. Victorian Institute of Earth and Planetary Sciences, Department of Earth Sciences, La Trobe University, Bundoora, 3083, Australia (email: rod.brown@latrobe.edu.au, geodxb@lure.latrobe.edu.au)

2. Department of Geology, Imperial College, London SW7 2BP, England (email: kerry@ic.ac.uk, r.harman@ic.ac.uk)

3. GEMOC National Key Centre, School of Earth Sciences, Macquarie University, NSW 2109, Australia (email: bill.griffin@mq.edu.au) and CSIRO Exploration and Mining, P.O. Box 136, N. Ryde, NSW 2113, Australia

4. De Beers Consolidated Mines Ltd., Geology Division, PO Box 7383, Centurion 0046, South Africa.

\section{Background}

Global surface heat flow data (Pollack et al. 1993) indicate that cratons are presently characterised by some of the lowest geothermal gradients on Earth (generally $\sim 10^{\circ} \mathrm{C} \cdot \mathrm{km}^{-1}$ ). Thermobarometry data from mantle xenoliths hosted by on-craton dimondiferous kimberlites, mostly of Paleozoic to Mesozoic age, generally document geotherms consistent with the low present day surface heat flow for these terrains. Furthermore, Archaean and Proterozoic ages inferred for diamonds from various localities and Re-Os isotopic data from sub-cratonic mantle xenoliths make a strong case for the extreme longevity of these low thermal gradients. Overall the available data indicate that low thermal gradients have persisted within many cratonic regions, in some places since the Archaean, and at least the Neoproterozoic more generally.

In addition to the abundant evidence for the extreme longevity of cold and thick cratonic lithosphere there is also mounting evidence which indicates that the these ancient cratonic roots can be destroyed by later tectonothermal events. For example, geochemical data for mantle xenoliths and alkaline magmas from the Sino-Korean craton indicate a dramatic thinning of the cratonic lithosphere from 180-220 km during the Palaeozoic to $<120 \mathrm{~km}$ by beginning of the Tertiary (Griffin et al., 1998a). A similar history of thinning is suggested for the Wyoming craton in North America (Eggler et al., 1988). Geochemical and fission track data from South Africa point to an analogous history of thinning for the lithospheric mantle beneath the Kaapvaal craton during the mid-Cretaceous.

\section{Kimberlites \& lithospheric mantle evolution}

Proton microprobe trace element analyses of $>700$ garnet concentrate garnets have been obtained from a wide range of kimberlites $(n=18)$, ranging in age from $140 \mathrm{Ma}$ to $80 \mathrm{Ma}$, from the Kaapvaal

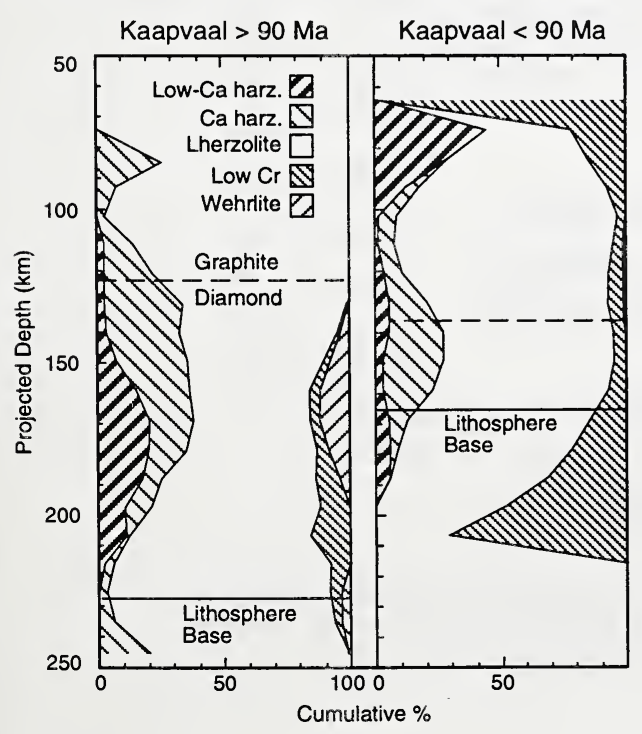

craton in South Africa. These data suggest that a major change in the composition and thermal structure of the lithosphere occurred beneath the craton over a short period at about $90 \mathrm{Ma}$ ago (Figure 1).

Kimberlites erupted prior to $90 \mathrm{Ma}$ sampled a harzburgite- rich (especially between $140-180 \mathrm{~km}$ ) lithosphere ca $210-220 \mathrm{~km}$ thick, which had a geotherm near the $34 \mathrm{~mW} \cdot \mathrm{m}^{-2}$ conductive model and was only mildly affected by melt-related metasomatism near the base. Kimberlites erupted after 90 Ma sampled a strongly modified lithosphere: about $80 \%$ of the volume at depths $>170 \mathrm{~km}$ was affected by melt-related metasomatism, the proportion of harzburgite was

Figure 1. Lithospheric sections beneath the Kaapvaal craton for two time slices (before $90 \mathrm{Ma}$ (left and after $90 \mathrm{Ma}$ (right)), constructed from data on concentrate garnets and xenoliths. The lithosphere base corresponds to the $1250{ }^{\circ} \mathrm{C}$ isotherm; the increase in geotherm associated with lithosphere thinning at ca $90 \mathrm{Ma}$ also has driven the graphite-diamond transition to greater depth. 
reduced significantly by metasomatic processes (Griffin et al., 1998b), the geotherm had risen to near a $40 \mathrm{~mW} \cdot \mathrm{m}^{-2}$ conductive model (as seen in many xenolith suites) and the lithosphere thickness had been reduced by approximately $40 \mathrm{~km}$.

\section{Fission track results \& erosion history}

Apatite fission track (FT) data from the Kaapvaal craton region indicate that over extensive areas the present land surface exposes rocks which resided at significantly elevated palaeotemperatures (in some places $>\sim 110^{\circ} \mathrm{C}$ ) as recently as $100-80 \mathrm{Ma}$ ago. However, the palaeotemperatures recorded by the FT data are not uniformly distributed across the craton. The current data indicate a general trend of increasing palaeotemperature towards the eastern and northern margins, and there are some regions that have not cooled significantly since the early Palaeozoic. For reasonable estimates of the palaeothermal gradient the distribution of palaeotemperature estimates imply substantial amounts of mid-Cretaceous denudation. In particular, FT results from the deep BK-1 bore hole $(1.5 \mathrm{~km})$ within the interior of the Kaapvaal craton document a mean cooling of $44 \pm 5^{\circ} \mathrm{C}$ and a mid-Cretaceous palaeogeothermal gradient of $13 \pm 5^{\circ} \mathrm{C}$, and the best estimate of the time of cooling is $90 \pm 10 \mathrm{Ma}$. If the eroded material had similar thermal properties to the underlying basement then $3.4 \pm 1.4 \mathrm{~km}$ of midCretaceous denudation is inferred for the BK-1 site. The data also confirm that over the last $\sim 500 \mathrm{Ma}$ the maximum near surface $(\leq \sim 10 \mathrm{~km})$ thermal gradient has never exceeded the present day value of ca $15^{\circ} \mathrm{C} . \mathrm{km}^{-1}$.

The high rates of mid-Cretaceous denudation implied for the Kaapvaal craton (100-300 m.Ma-1) are corroborated by a dramatic peak in the rate of clastic sediment accumulation within the adjacent Mozambique basin (eastern margin) as well as increased rates within the Orange basin (western margin) (Figure 2). Onshore, this period of enhanced erosion is recorded by the wide occurrence of the mid-late Cretaceous Malvernia Formation along the northwestern margins of the craton: an accumulation of poorly sorted sandstones and pebble and boulder conglomerates comprising coalesced alluvial fans and major fluvial channel/floodplain systems (Botha and de Wit, 1996). MidCretaceous denudation of the craton interior is also supported by the abundance of eroded on-craton kimberlite intrusions (and related alkaline rocks) with intrusive ages of 95-85 Ma. However, the preservation of terrestrial gravels at Mahura Muthla (near Lichtenburg), dated as Late Cretaceous (T.C. Partridge pers. comm., 1997), indicates that major erosion had essentially ceased in the northwestern interior region of the craton by the end of the Cretaceous.

\section{Mozambique Basin Sedimentation}

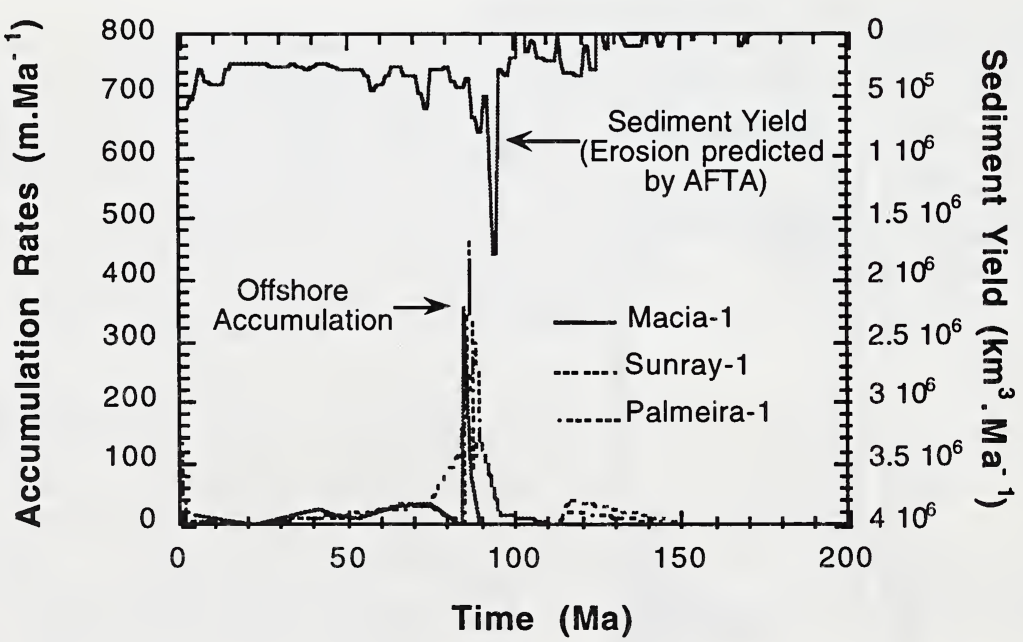

Figure 2. Comparison of offshore sedimentation rates for three boreholes (Macia-1, Sunray-1, Palmeira-1) within the proximal Mozambique basin and the average onshore erosion rate estimated from FT data for the Kaapvaal craton. 


\section{Conclusions}

We suggest that the enhanced rates of denudation were caused, in part at least, by regional uplift of the Kaapvaal craton at approximately $90 \mathrm{Ma}$. The uplift was probably driven by bouyancy forces arising from a decrease in the mean density of the underlying lithosphere. The erosion of the buoyant Archean lithosphere and its replacement by denser asthenospheric material would effectively increase the density of the column, if the process were isothermal (Griffin et al., 1998c). However, the concentrate data indicate that the lithosphere thinning was accompanied by an overall (transient?) rise in the geotherm, accompanying the thinning of the mechanical boundary layer by $40 \mathrm{~km}$. This heating could provide the density decrease required for uplift, and it may have been enhanced by compositional changes related to metasomatic processes. We therefore believe that the mid-Cretaceous geomorphological history of the Kaapvaal craton and the eruption of the main phase of Group I kimberlites are both genetically linked to the thermo-chemical changes that took place within the underlying lithospheric mantle approximately 90 Ma ago.

\section{References}

Botha, G.A. and de Wit, M.C.J. 1996. Post-Gondwanan continental sedimentation, Limpopo region, southeastern Africa. J. Afr. Earth Sci., 23, 163-187.

Eggler, D.H., Meen, J.K., Welt, F., Dudas, F.O., Furlong, K.P., McCallum, M.E. and Carlson, R.W. 1988. Tectonomagmatism of the Wyoming Province. Colo. Sch. Mines Q. 83, 25-40.

Griffin, W.L., Zhang A., O'Reilly, S.Y. and Ryan, C.G. 1998a. Phanerozoic evolution of the lithosphere beneath the Sino-Korean Craton. In: Mantle Dynamics and Plate Interactions in East Asia (Flower, M., Chung, S.L., Lo, C.H. and Lee, T.Y., eds). Amer. Geophys. Union Spec. Publ., (in press).

Griffin, W.L., Shee, S.R., Ryan, C.G., Win, T.T. and Wyatt, B.A. 1998b. Harzburgite to lherzolite and back again: Metasomatic processes in ultramafic xenoliths from the Wesselton kimberlite, Kimberley, South Africa. Contr. Mineral. Petrol. (submitted).

Griffin, W.L., O'Reilly, S.Y., Ryan, C.G., Gaul, O. and Ionov, D. 1998c. Secular variation in the composition of subcontinental lithospheric mantle. In J. Braun, J. C. Dooley, B. R. Goleby, R. D. van der Hilst and C. T. Klootwijk (eds) Structure \& Evolution of the Australian Continent, Geodynamics Volume 26, Amer. Geopyhys. Union, Washington D.C. pp. 1-26.

Pollack, H.N., Hurter, S.J. and Johnson, J.R. 1993. Heat flow from the Earth's interior: analysis of the global data set. Rev. Geophys., 31, 267-280. 